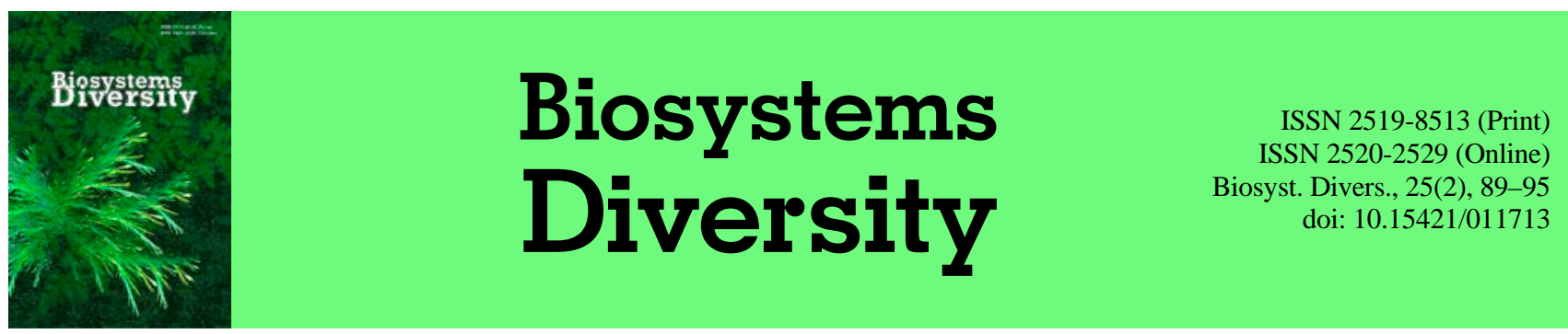

\title{
Research on the impact of polyhexamethyleneguanidine on the plant component of biocenoses
}

\author{
A. V. Lysytsya \\ Rivne State University of Humanities, Rivne, Ukraine
}

Article info

Received 19.04.2017

Received in revised form 07.05.2017

Accepted 10.05.2017

Rivne State University of Humanities, Plastova Str., 29a, 203, Rivne, 33028, Ukraine. Tel.: +38-097-33-22-466. E-mail: lysycya@ukr.net

\begin{abstract}
Lysytsya, A. V. (2017). Research on the impact of polyhexamethyleneguanidine on the plant component of biocenoses. Biosystems Diversity, 25(2), 89-95. doi:10.15421/011713
\end{abstract}

This article analyses the results of studying the influence of polymeric guanidine derivatives, namely polyhexamethyleneguanidine chloride (PHMG), on land and freshwater plants. Gas chromatography was used to determine the soil - plant and water - plant transition coefficients. Methods of mass spectrometry and photocalorimetry were used to identify the PHMG in the samples. We investigated the toxicity of PHMG for freshwater flora in an aquarium on Vallisneria spiralis, Riccia fluitans and Chlorella pyrenoidosa. The results showed that even the lowest bactericidal concentrations of the preparation $\left(10^{-3} \%\right.$ or $\left.10 \mathrm{mg} / \mathrm{L}\right)$ caused the death of test organisms within one to two days. Onetime application of PHMG to the aquarium in dose of $10^{-4} \%$ (or $1 \mathrm{mg} / \mathrm{L}$ ) did not cause any noticeable changes in algae during the 7 days of the experiment. The PHMG transfer coefficient did not exceed $0.1 \%$ for the system "water - algae tissue". Moreover, the initial concentration of the drug in the water decreased by almost ten times already during the first two days. PHMG polycation molecules quickly bind to dissolved in water organic and inorganic substances, suspended particles, microorganisms, etc. Flocculation causes a sharp decrease in the number of active "free" polycation molecules in water. The drug settles on the bottom of the aquarium and then is destroyed by bacteria saprophytes. Apparently, PHMG is included in their metabolism and serves as nitrogen source for microorganisms Pseudomonas putida, Flavobacterium columnare, Bacillus sp., Sarcina sp., Nitrosomonas sp. and Nitrobacter sp. At the same time, this study showed that the safe concentration of PHMG for hydrobionts in the water of natural fresh water reservoirs is $0.01 \mathrm{mg} / \mathrm{l}$, or $10^{-6} \%$, provided the drug is chronic. Ground plants are more resistant to the action of PHMG. They easiliy tolerate finely dispersed spraying with $0.3 \%$ aqueous solution of PGMG chloride in a dose of $0.5-1.0 \mathrm{l} / \mathrm{m}^{2}$. For Urtica dioica, Artemisia absinthium, Taraxacum officinale and Poa angustifolia the coefficients of transfer of the preparation from the surface of plants to internal tissues did not exceed $0.01 \%$. And the coefficients of transfer of PHMG from soil to plants were in the range of $0.004-0.008 \%$. We conducted environmental monitoring in Rivne region during 20112015. It showed that numerous cases of use of PGMG drugs for disinfection of various agricultural objects did not lead to any noticeable negative consequences for natural biocenoses. Consequently, we can assume that the preparations of PHMG do not pose a serious threat to the vegetative component of ecosystems. Migration of the drug is minimal in food chains in soil and water.

Keywords: polyalkilenguanidines; ecosystems; transition coefficients; monitoring; toxicity

\section{Визначення впливу полігексаметиленгуанідину на рослинну складову біоценозів}

\author{
А. В. Лисиця \\ Рівненський державний гуманітарний університет, Рівне, Украӥна
}

Розглянуто особливості впливу полімерних похідних гуанідину, зокрема полігексаметиленгуанідину гідрохлориду (ПГМГхл), на наземну та прісноводну рослинність. ПГМГхл - досить поширений і ефективний дезінфектант. Разом із тим, з'ясувалося, що навіть мінімальні його бактерицидні концентрації $\left(10^{-3} \%\right.$, або 10 мг/л) токсичні для фітогідробіонтів. За одноразової дії безпечною для водних рослин можна вважати концентрацію ПГМГхл 1 мг/л (або 10\%) і нижче. За тривалої дії ГДК для природних водойм не повинна перевищувати 0,01 мг/л, або $10^{-6} \%$. Коефіцієнт переходу «вода - водорость» - не більше $0,1 \%$. Для наземних трав’янистих рослин коефіцієнти переходу ПГМГхл із грунту або поверхні рослини у внутрішні органи та тканини не перевищують $0,01 \%$. Охарактеризовано закономірності поведінки ПГМГхл в екосистемах. У гідроценозах молекули цього полікатіона швидко нейтралізуються через взаємодію 3 розчиненими у воді неорганічними та органічними речовинами, колоїдами, зваженими частинками тощо. Внаслідок флокуляції ПГМГхл осідає на дно, де розкладається бактеріями-сапрофітами. У воді або грунті можливість міграції по ланцюгах живлення мінімальна. Екологічний моніторинг показав, що численні випадки застосування у 2011-2015 рр. ПГМГ-вмісних дезінфектантів на об’єктах господарювання в Рівненській області не спричинили скільки-небудь помітні негативні наслідки для біоценозів. Препарати ПГМГхл можна вважати порівняно безпечними для рослинної складової екосистем.

Ключові слова: поліалкіленгуанідини; екосистеми; коефіцієнти переходу; моніторинг; токсичність 


\section{Вступ}

Усе ширше застосування дезінфектантів та інших препаратів, які виготовляють на основі полімерних похідних гуанідину, або поліалкіленгуанідинів (ПАГів) вимагає ретельного вивчення тих потенційних загроз, які ці сполуки можуть нести як для людини, так і для довкілля. Незважаючи на низку переваг (хороші дезінфікувальні властивості, тривала дія, відсутність хімічної агресивності щодо поверхонь, які обробляють, добра розчинність у воді, низька летючість, відсутність запаху та необхідності використання індивідуальних засобів захисту тощо), питання впливу цих препаратів на окремі складові біоценозів, їх екологічна безпечність вивчені недостатньо.

Типові представники групи ПАГів - це полігексаметиленгуанідину гідрохлорид (ПГМГхл) і полігексаметиленбігуанідин (ПГМБ). Бактерицидні концентрації ПГМГхл та ПГМБ у водних розчинах залежно від умов дезінфекції становлять 0,001-1,0\% (бактеріостатичні - 0,0001-0,005\% і вище), для мікобактерий туберкульозу $0,5-4,0 \%$, вірусоцидні - 0,0001-0,5\%, а фунгіцидні - 0,05-4,0\% (Moore et al., 2008; Mathurin et al., 2012; Prasanthi et al., 2012).

Досить поширена думка, що біоцидна активність ПГМГхл відносно прокаріотичних організмів (бактерії, археї) та вірусів значно вища, ніж щодо еукаріотів (Vointseva and Gembitsky, 2009). Вважається, що дезінфектанти, виготовлені на основі ПГМГхл, поєднують у собі дві важливі характеристики: 3 одного боку - добре виражені бактерицидні та вірусоцидні властивості (останнє стосується переважно оболонкових вірусів), з іншого - безпечність для вищих організмів, людини та екосистем (Oule et al., 2012; Chakraborty et al., 2014; Mashat, 2016). Ця різниця може бути пояснена різними біохімічними та біофізичними механізмами дії ПАГів на клітини прокаріот i еукаріотів. Проте одностайної думки щодо цих механізмів серед дослідників наразі немає. Переважає думка, що біоцидна вибірковість ПГМГ або ПГМБ перш за все пов'язана з мембранодеструктивною дією препаратів. Низка досліджень свідчить, що молекули цих полікатіонів незворотно зв'язуються 3 фосфоліпідами цитоплазматичної мембрани (ЦПМ) і за бактеріостатичних концентрацій змінюють іiі іонну проникність, електричний потенціал, роботу трансмембранних ферментних систем, а за бактерицидних - спричиняють пертурбацію ліпідного бішару, руйнування ЦМП і загибель клітини (Zhou et al., 2011; CarmonaRibeiro and de Melo Carrasco, 2013; Choi et al., 2017).

Зрозуміло, що мембрани бактерій за своєю будовою суттєво відрізняються від ЦПМ еукаріотичних клітин. Перш за все звертає на себе увагу різний фосфоліпідний склад (Timofeeva and Kleshcheva, 2011; Lysytsya et al., 2015). У бактерій зовнішній ліпідний моношар ЦПМ містить переважно негативно заряджені або «кислі» фофоліпіди (фосфатидилсерин, фосфатидилінозітол, фосфатидилгліцерол, кардіоліпін), що й зумовлює негативний потенціал на поверхні. Це значно полегшує адсорбцію позитивно зарядженої молекули ПГМГхл на ЦПМ. У еукаріотичних клітин, у тому числі соматичних клітин людини (хіба що за винятком тромбоцитів), у зовнішньому моношарі кислі ліпіди практично відсутні, а переважають цвітер-іони (фосфатидилхолін, фосфатидилетаноламін, сфінгомієлін). Тому їх ЦМП ззовні має зазвичай позитивний заряд, що, теоретично, має ускладнювати процес адсорбції полікатіона на поверхню клітини.

За іншою версією, полікатіон ПГМБ проникає всередину клітини та міцно зв'язується з бактеріальною хромосомою (поліаніон), яка не захищена ядерною мембраною. Це спричинює інактивацію бактеріальної ДНК і загибель клітини (Chindera et al., 2016). А ось в еукаріотичних клітинах молекули препарату у цитоплазмі ізолюються в ендосомах і потрапити в ядро клітини не можуть. Як додатковий аргумент автори наводять приклад катіонних антимікробних пептидів (АМП), які вважаються важливою складовою вродженого імунітету. Такий механізм (ендосоми) захищає клітини господаря, у першу чергу їх ДНК і РНК, від ендогенних АМП і, можливо, від інших полікатіонів, у тому числі ПГМБ і ПГМГхл.
Проте пошкодження хромосом як один із можливих механізмів біоцидної дії ПГМБ описано також і для еукаріотичної Leishmania major (Firdessa et al., 2015).

У водні середовища ПГМГхл може поступати декількома шляхами: 1) випадкове потрапляння у водойми (або спочатку у грунт) під час проведення дезінфекції чи деконтамінації об'єктів ветеринарно-санітарного нагляду або комунального господарства, 2) порушення технологічних процесів, неконтрольовані промислові викиди деревообробної, хімічної, будівельної, харчової промисловості тощо, 3) знезараження стічних або каналізаційних вод, рідких відходів виробництва, 4) дезінфекція знарядь лову в рибних господарствах або знезараження та очищення водойм.

У грунт ПАГи можуть потрапляти також унаслідок проведення дезінфекції та, крім того, під час обробки рослин. Зокрема, низка авторів свідчать, що ПГМГ може сприяти росту та розвитку овочевих культур (Opryshko, 2013), кукурудзи (Klimenko, 2014), стимулювати проростання насіння (Lysytsya et al., 2013). Препарати ПГМГ гальмують розвиток пероноспорозу цибулі, ефективні проти бактерій, які викликають бурий бактеріоз картоплі, а томати захищають від раку (Vointseva and Gembitsky, 2009).

ПГМГ добре адсорбується грунтом і слабо десорбується у воду, тому імовірність його потрапляння у водойми незначна (Chang et al., 2006). Лабораторні дослідження біорозкладання ПІГМБ показали, що деякі види бактерій грунту, зокрема Pseudomonas putida, можуть використовувати цю сполуку як джерело азоту (O’Malley et al., 2006). Потрапляючи у водойми, ПАГи швидко переходять у донну фазу, де, за дії мікроорганізмів активного мулу, суттєво прискорюються процеси їх природної біодеструкції. Під час випробування ПАГів за стандартною методикою оцінювання біорозкладання флокулянтів установлено, що вони розкладаються на $80 \%$ за один прохід через шар активного мулу (Vointseva and Gembitsky, 2009). Серед продуктів деструкції ПГМГ потенційну загрозу для гідробіонтів у першу чергу може становити гексаметилендіамін і його солі, які вважають досить токсичними сполуками (II клас небезпеки, LD 50 для лабораторних тварин $\approx 250$ мг/кг). Гексаметилендіамін у стічних водах може знешкоджуватися амінооксидазою Bacillus subtilis у донних відкладах водойм. При цьому утворюється аміак і гідрогену пероксид, інші продукти деструкції полімеру (аліфатичні альдегіди) метаболізуються багатьма видами мікроорганізмів і не становлять загрози для водних біоценозів (Vointseva and Gembitsky, 2009).

Нині питання впливу ПАГів, зокрема ПГМГхл, на довкілля вивчене недостатньо, що створює низку потенційних загроз для екосистем. Якщо виходити 3 наведених вище аргументів, можна припустити, що бактерицидні концентрації препарату, а це як мінімум $10^{-4}-10^{-3} \%$, повинні бути малотоксичними для вищих організмів. Тому виникає потреба в експериментальній перевірці біоцидної дії ПГМГхл на прокаріотичні та еукаріотичні організми. Недостатньо дослідженою також залишається проблема подальшої долі цих сполук в екосистемах (можливість ïx міграції, у тому числі по ланцюгах живлення, та коефіцієнти переходу, накопичення та біологічне розкладання тощо).

Виходячи із цього, мета досліджень - порівняти дію ПГМГхл на про- та еукаріотичні організми, дослідити потенційно можливий негативний вплив препарату на рослини, у тому числі водні, визначити коефіцієнти переходу препарату в рослини, спрогнозувати можливі наслідки використання ПАГів для гідроценозів та мікробіоценозів грунту.

\section{Матеріал і методи досліджень}

Полігексаметиленгуанідину гідрохлорид (ПГМГхл) виробництва ПП «Терміт» (м. Рівне, Україна). Середня молекулярна маса полімеру становила 3-5 кДа, кількість потенційно токсичних низькомолекулярних домішок не перевищувала $0,5 \%, \mathrm{pH}$ водних розчинів - 6,0-7,5. Найменування ПГМГ гідрохлориду за класифікацією IUPAC: полі(імінокарбонімідоіліміно-1,6- 
гександиїл) гідрохлорид, назва англійською - Poly(iminocarbonimidoylimino-1,6-hexanediyl), monohydrochloride (CAS: 9140350-8, RN: 57029-18-2), проте частіше вживається назва «polyhexamethyleneguanidine hydrochloride».

Як тест-об’єкти використано наземні рослини, які зазвичай поширені поблизу тваринницьких ферм, пташників, господарських споруд та інших об’єктів, що підпадають обробці деззасобами. Це, зокрема, кропива дводомна (Urtica dioica Linnaeus, 1753), полин гіркий (Artemisia absinthium Linnaeus, 1753), кульбаба звичайна (Taraxacum officinale F. H. Wigg, 1780), тонконіг лучний (Poa angustifolia Linnaeus, 1753). Польові дослідження проводили в 2011-2015 pр. на території Рівненської області. Зразки рослин відбирали на дослідних ділянках у Костопільському, Рівненському та Гощанському районах під час вегетації (травень - вересень) через 1-3 доби після обробки препаратами ПГМГхл.

Під час визначення загальної токсичності та коефіцієнтів переходу (КП) для системи «вода - рослина» в модельних акваріумних дослідах використано валіснерію спіральну (Vallisneria spiralis Linnaeus, 1753), річчію плаваючу (Riccia fluitans Linnaeus, 1753) та хлорела (Chlorella pyrenoidosa H. Chick, 1903). Водорості розміщали у стандартні лабораторні акваріуми об'ємом 10-100 дм³, тривалість освітлення - до 10-12 годин на добу, штучна аерація, температура води $+19 \ldots+25{ }^{\circ} \mathrm{C}$, $\mathrm{pH}-6,5-7,5$. Вихідна концентрація ПГМГхл у воді становила $1 \times 10^{-4} \%$, або 1 мг/л, у молярному вираженні $\approx 7$ мкМоль/дм ${ }^{3}$.

В експериментах із біорозкладання ПГМГхл досліджували загальну чисельність сапрофітної мікрофлори акваріума, зокрема Pseudomonas putida Trevisan, 1889, Flavobacterium columnare Bernardet and Grimont, 1989, Bacillus sp., Sarcina sp., Nitrosomonas sp., Nitrobacter sp. Ідентифікацію проводили методом світлової мікроскопії за визначником бактерій Берджі, для досліджень відбирали по 0,1 см³ мулу. Тест-об'єктами для визначення біоцидної дії ПГМГхл також виступали синьозелені водорості (ціанобактеріi) Spirulina (Arthrospira) i Nostoc.

Коефіцієнти переходу для систем «грунт - рослина», «вода рослина» розраховували за формулою:

$$
\mathrm{K \Pi}(\%)=\mathrm{C}_{1} / \mathrm{C}_{2} \times 100 \% \text {, }
$$

де $\mathrm{C}_{1}$ - концентрація ПГМГхл в об'єкті (тканини рослин), $\mathrm{C}_{2}-$ вихідна концентрація у воді або внесена доза у грунті.

У кожному досліді використано щонайменше по 10 екземплярів рослин певного виду.

Визначаючи КП для системи «грунт - наземна рослина», поверхню експериментальної ділянки обробляли 0,5\% водним розчином ПГМГхл, який у дозі 1,0 л/м² вносили прикоренево, не допускаючи потрапляння на будь-які відкриті частини рослин, що вегетують. Ірунти на дослідних ділянках типові для Рівненської області, переважно дерново-підзолисті, в окремих випадках сірі, опідзолені або дерново-оглеєні. Середньозважений показник забезпеченості гумусом становив 1,8-2,5\%, зволоженість середня, рівень нітратів мінімальний. Середньозважений показник кислотності для ділянок у Костопільському районі (зона Полісся) коливався в межах 5,0-5,3, у Рівненському та Гощанському районах (зона Лісостепу) - $\mathrm{pH}=6,0-7,0$. Вміст ПГМГхл через 1-3 доби визначали у тканинах стебла та листків.

В іншій серії дослідів поверхню рослин обприскували $0,3 \%$ водними розчинами ПГМГхл у дозі $0,5-1,0$ л/м² і через $1-$ 3 доби визначали вміст препарату у внутрішніх тканинах стебла або кореня. Після ретельного промивання проточною водою верхні шари органів знімали та видаляли.

Для виділення ПГМГхл із тканин наземних рослин відбирали по 150-250 г цільних рослин (із корінням), обтрушували частинки грунту (за необхідності), ретельно промивали проточною водою, подрібнювали ножем необхідні частини рослин, після перемішування із суміші відбирали 120-130 г і подрібнювали в гомогенізаторі. Потім у конічну колбу місткістю $500 \mathrm{~cm}^{3}$ із притертим корком відбирали $100 \pm 0,5$ г гомогенату 3 точністю $\pm 0,01$ г, додавали $100 \mathrm{~cm}^{3}$ цитратного буферу (pH 2,8).
Колбу закорковували, отриману суміш перемішували на струшувачі протягом години, осад відділяли центрифугуванням (5 000 об./хв 15 хв), супернатант зливали в конічну колбу. Екстракцію повторювали ще двічі, об’єднаний екстракт випаровували на роторному випаровувачі $(+45 \ldots+50$ C) до мінімального об’єму, після чого зразок кількісно розчиняли в гліциновому (pH 3,5) або

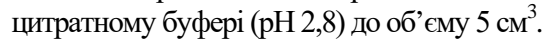

Для коректного розрахунку КП кінцеву кількість екстракту $\left(5 \mathrm{~cm}^{3}\right)$ приводили до вихідної маси гомогенату (100 г), тобто коефіцієнт перерахунку становив 20. Також ураховували те, що лише для водоростей була точно відома концентрація ПГМГхл у середовищі (воді акваріума). У дослідах з обприскування наземних рослин оперували лише загальною дозою препарату відомої концентрації на одиницю площі поверхні. Під час внесення ПГМГхл у грунт також була відома лише загальна кількість препарату на одиницю площі, тому в даному випадку значення КП досить умовне, а похибка вимірювань враховувала лише «інструментально-методичну» їх складову. Як контроль використовували аналогічно отримані екстракти рослин, які не були піддані обробці препаратом і в які вносили на кінцевому етапі відому кількість ПГМГ (внутрішній стандарт).

Визначення концентрації ПГМГхл у воді (природні водойми, акваріумні модельні екосистеми) проводили фотоколориметрично за Vointseva and Gembitsky (2009). Метод грунтується на утворенні солями ПГМГ з індикатором-барвником еозином Н (1,3,6,8-тетрабром-флуоресцеїн) у кислому середовищі (гліциновий буфер, pH 3,5) забарвленої комплексної сполуки 3 кольором від оранжевого до інтенсивно-рожевого. Оптичну густину визначали на фотоелектроколориметрі КФК-2 або спектрофотометрі СФ-46 не пізніше ніж через 10 хв після внесення в досліджуваний зразок індикатора (еозину Н) за довжини хвилі 540 нм із використанням кювет товщиною 50 або 10 мм. За результатами вимірювань оптичної густини еталонних розчинів попередньо будували калібрувальний графік, знаходили вміст ПГМГхл у досліджуваному зразку. В інтервалі

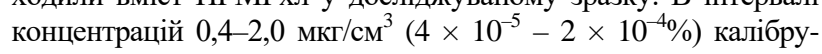
вальний графік має вигляд прямої лінії. За результат аналізу брали середнє арифметичне трьох паралельних визначень, абсолютна розбіжність між якими не перевищувала допустиме відхилення в $1 \%$. Відносна похибка результатів аналізу $\pm 5 \%$. В окремих випадках необхідно було концентрувати розчини в 10-100 разів шляхом упарювання (термостат, $\left.\mathrm{t} \approx 70{ }^{\circ} \mathrm{C}\right)$. Для визначення низьких концентрацій ПГМГхл замість гліцинового використовували цитратний буфер (суміш цитрату натрію в концентрації 0,5 моль/дм ${ }^{3}$ із доведенням хлоридною кислотою до рН 2,8), кювета для фотометрії з товщиною поглинального шару 50 мм. Методика дозволяє визначати концентрацію ПГМГхл у воді в діапазоні $10^{-5}-10^{-4} \%$.

Вміст препарату у тканинах рослин визначали на хроматографі «Цвет 500». Метод грунтується на лужному гідролізі полімеру з утворенням гексаметилендіаміну та його газохроматографічному визначенні у вигляді трифторацетильних похідних із використанням термоіонного або полум'яно-іонізаційного детектора (Vointseva and Gembitsky, 2009). До екстрактів рослин додавали по $1 \mathrm{~cm}^{3} 20 \%$ водного розчину $\mathrm{NaOH}$, i проводили гідроліз упродовж двох годин на водяній бані $\left(80{ }^{\circ} \mathrm{C}\right)$. Після гідролізу розчин нейтралізували хлоридною кислотою та проводили хроматографічне визначення вмісту гексаметилендіаміну. Як контроль використовували екстракти, в які попередньо вносили відомі кількості препарату. Цей метод на порядок чутливіший, ніж колориметричний, межа визначення ПГМГхл становила 0,05 мг/кг, або $5 \times 10^{-6} \%$.

Ідентифікацію ПГМГхл у зразках проводили із застосуванням методу часопролітної плазмово-десорбційної мас-спектрометрії або TOF-PDMS, (time-of-flight plasma desorption mass spectrometry) (Macfarlane and Torgerson, 1976; Sysoev and Artaev, 1991). Дослідження проводили на мас-спектрометрі біохімічному МСБХ-01 (АТ «SELMI», м. Суми, Україна) 3 іонізацією зразка уламками поділу ядер ${ }^{252} \mathrm{Cf}$, гранична 
чутливість - 1 пМоль (Knysh et al., 1989). Вміст амонійного азоту у воді визначали за загальноприйнятою методикою 3 використанням реактиву Неслера на КФК-2.

\section{Результати}

За даними моніторингу який проводили протягом 20112015 років у Рівненський області, препарати ПГМГ використовували для дезінфекції та деконтамінації низки об'єктів ветеринарно-санітарного нагляду (свиноферми, тваринницькі комплекси, бойні, рибні господарства, склади, технічні приміщення агропідприємств тощо) в низці господарств Березнівського, Гощанського, Зарічнянського, Здолбунівського, Костопільського, Сарненського та Рівненського районів. У прилеглі водойми препарат потрапляв двома основними шляхами: внаслідок змивання решток дезінфектанту з об'єктів дезінфекції (стічні, дощові води), або після обробки знарядь лову, обладнання та інвентаря товарних рибних господарств. Зразки води відбирали в чотирьох ставках Гощанського району. Наявність у воді залишкових кількостей ПГМГхл визначали фотоколориметричним методом. У всіх зразках вміст ПГМГхл був нижчим за $1 \times 10^{-5} \%$, практично перебуваючи на межі чутливості методу. Концентрація $10^{-5} \%$ або 0,1 мг/дм ${ }^{3}$ відповідає встановленому рівню ГДК у воді.

В одному експерименті змодельовано «техногенну аварію»: у водойму (занедбаний нетоварний рибний ставок) локально внесено досить велику кількість $\left(5 \mathrm{дm}^{3}\right)$ деззасобу Епідез (20\% розчин ПГМГхл). Це спричинило загибель протягом перших 5-10 годин значної кількості гідробіонтів (водорості, ракоподібні, молюски, пуголовки, мальки риб тощо) в радіусі до 15 м навколо місця внесення. Лабораторний аналіз зразків води, відібраних через добу в інших місцях водойми, показав, що концентрації ПГМГхл перебували в межах ГДК, тобто $<10 \%$, лише в місці внесення препарату $-4 \times 10^{-3} \%$. Через тиждень у місці внесення залишилися тільки «слідові» кількості ПГМГхл $10^{-5} \%$. Вміст у воді гексаметилендіаміну (одного з найтоксичніших продуктів розпаду препарату) не перевищував установлену ГДК $\left(0,01\right.$ мг/л, або $\left.10^{-6} \%\right)$. У межах $20-40 \%$ зросла концентрація амонійного азоту (одного з продуктів біодеструкції ПГМГхл). Через три тижні явно виражених негативних наслідків для всього гідроценозу не спостерігали, видовий склад макрогідробіонтів не змінився. Разом із тим, через чотири тижні, незважаючи на залишок лише «слідових» кількостей препарату, в місці «техногенної аварії» мікробіоценоз так повністю і не відновився.

У першій серії лабораторних досліджень з V. spiralis, R. fluitans i Ch. pyrenoidosa визначали граничну межу токсичності ПГМГхл. За концентрації препарату у воді акваріума $10^{-2} \%$ усі водорості гинуть упродовж перших 2-5 годин. У хлорели світлова мікроскопія показала часткове руйнування протопласту. Концентрація $10^{-3} \%$ виявилася гостротоксичною, практично всі випробувані тест-об'єкти загинули упродовж першої-другої доби. Вихідна концентрація $\left(10^{-4} \%\right.$, або 1,0 мг/л) не викликала скільки-небудь помітних змін у водоростей протягом 7 діб спостережень. Світлова мікроскопія також не виявила значних морфологічних змін. Остання концентрація ПГМГхл

Таблиця 2

Вплив різних концентрацій ПГМГхл на загальну чисельність сапрофітної мікрофлори акваріума $(\mathrm{M} \pm \mathrm{m}, \mathrm{n}=10)$

\begin{tabular}{lccc}
\hline \multirow{2}{*}{ Вихідна концентрація ПГМГхл, \% } & \multicolumn{3}{c}{ Відносна сумарна чисельність сапрофітних бактерій, \% } \\
\cline { 2 - 4 } & 1-ша доба & 2-га доба & 3-тя доба \\
\hline $5,0 \times 10^{-3}$ & $10,25 \pm 1,83$ & $30,52 \pm 1,45^{*}$ & $70,15 \pm 3,35^{*}$ \\
$5,0 \times 10^{-4}$ & $50,18 \pm 3,16^{*}$ & $80,45 \pm 8,73$ & $205,22 \pm 13,53 *$ \\
$5,0 \times 10^{-5}$ & $80,27 \pm 3,45^{*}$ & $101,21 \pm 4,26^{*}$ & $110,25 \pm 7,35$ \\
Контроль (без ПГМГха & $490,25 \pm 25,52 *$ & $112,53 \pm 5,15 *$ \\
\hline
\end{tabular}

Із таблиці 2 видно, що небіоцидні концентрації препарату $\left(<10^{-4} \%\right)$ вже на 3-4-ту добу спричиняють зростання чисельності окремих видів бактерій-сапростофів. У воді контрольно- використана в таких експериментах у модельних мікроекосистемах акваріума під час визначення коефіцієнтів переходу (КП) препарату в рослини.

Для кількісного визначення вмісту ПГМГ у всіх частинах рослин застосовано метод газової хроматографії, а для ідентифікації- мас-спектрометрію (рис. 1).

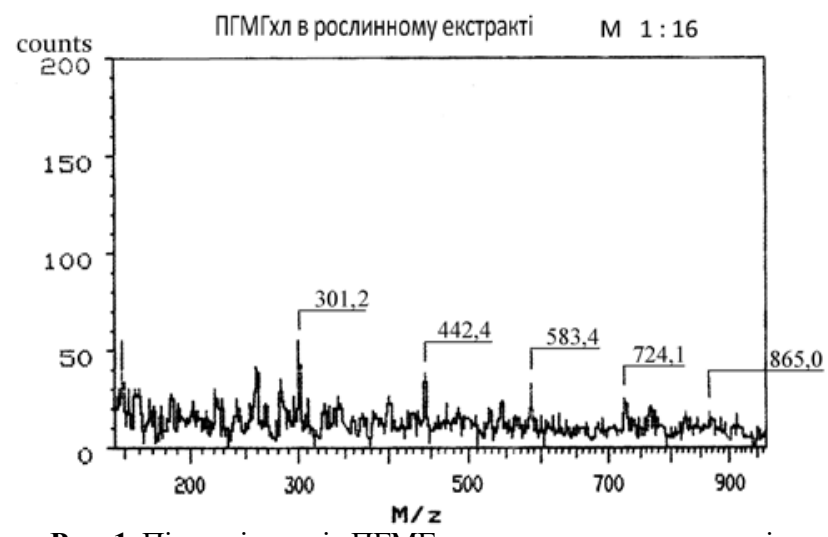

Рис. 1. Піки олігомерів ПГМГхл у рослинному екстракті, мас-спектр TOF-PDMS

На мас-спектрі наявні такі піки протонованих молекул [ $\mathrm{Mn}^{+}$ $\left.\mathrm{H}^{+}\right]^{+}$олігомерів ПГМГхл: m/z 301, 442, 583, 724 і 865, де $\mathrm{n}=2$, $3,4,5$, 6. Визначені іони мають характерні для олігомерів ПГМГ молекулярні маси, які відрізняються на один мономер $(\Delta \mathrm{m} / \mathrm{z}=\approx 141)$. Як «відбитки пальців», ці іони дозволяють чітко виявити присутність препарату у досліджуваному субстраті.

Під час визначення КП «вода - рослина» 3'ясувалося, що для використаних нами як тест-об'єкти водоростей вони не перевищують $0,1 \%$ (табл. 1). Зразки відбирали через дві доби після внесення препарату в акваріум, екстракти концентрували випарюванням.

\section{Таблиця 1}

Коефіцієнти переходу ПГМГхл у системі «вода - рослина» $(\mathrm{M} \pm \mathrm{m}, \mathrm{n}=10)$

\begin{tabular}{lccc}
\hline \multicolumn{1}{c}{ Вид } & $\begin{array}{c}\text { Вихідна (внесена } \\
\text { у воду) концентрація } \\
\text { ПГМГхл, } C_{2} \text {, мг/л }\end{array}$ & $\begin{array}{c}\text { Кінцева концентрація } \\
\text { ПГМГхл у тканинах } \\
\text { рослини, } C_{1}, \text { мкг/кг }\end{array}$ & КП, \% \\
\hline V. spiralis & $1,00 \pm 0,05$ & $0,751 \pm 0,135$ & 0,075 \\
R. fluitans & та сама & $0,915 \pm 0,052 *$ & 0,091 \\
Ch. pyrenoidosa & та сама & $0,807 \pm 0,114$ & 0,081 \\
\hline
\end{tabular}

Примітка: * - тут і в наступних таблицях відмінності показників щодо контролю вірогідні за $\mathrm{P}<0,05$.

Експерименти із синьо-зеленими водоростями Spirulina i Nostoc виявили, що біоцидні концентрації ПГМГхл для них перебувають на тому самому рівні $\left(10^{-3}-10^{-2} \%\right)$. Таким чином, припущення про можливість застосування цього дезінфектанту для боротьби 3 цвітінням водойм у літній період не підтвердилося. Такі високі концентрації препарату становлять смертельну загрозу для інших гідробіонтів.

Досліди із сапрофітною мікрофлорою акваріума показали, що, залежно від концентрації, ПГМГхл може як інгібувати їх розвиток, так і навпаки - стимулювати (табл. 2). 
фіковано P. putida, Flavobacterium columnare, Bacillus sp., Sarcina sp., Nitrosomonas sp. i Nitrobacter $s p$. Під час експерименту рН води суттєво не змінювалася $(6,8-7,6)$, температура залишалась сталою $\left(+22 \ldots+23{ }^{\circ} \mathrm{C}\right)$, у перші дні в $1,5-2,0$ рази зростала концентрація амонійного азоту - одного із продуктів біодеструкції ПГМГхл.

Інший дослід показав досить стрімку динаміку зменшення вихідної концентрації ПГМГхл: $0,001 \%$ у воді протягом перших декількох діб після його внесення в модельну екосистему акваріума (рис. 2).

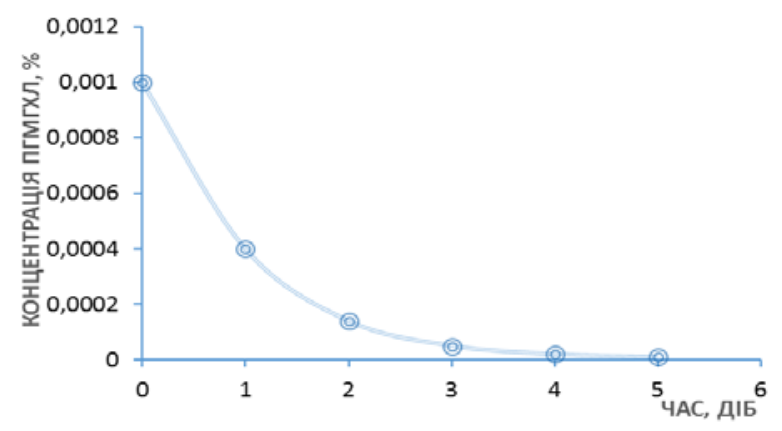

Рис. 2. Динаміка зміни концентрації «вільного» ПГМГхл у воді акваріума

Вміст «вільних молекул» препарату в воді різко зменшується вже в першу добу. Це відбувається внаслідок зв'язування полікатіона з розчиненими у воді органічними та неорганічними речовинами, зваженими частинками, подальшого осідання на дно акваріума (флокуляція) та біологічного розкладання. На другу добу концентрація ПГМГхл фактично знижується до безпечної, а на третю - навіть до «стимулювальної» для окремих видів сапрофітних мікроорганізмів (тих, що пережили початкову «ударну» дозу препарату). Через залучення ПГМГхл до їх метаболічних процесів акумульовані в осаді залишки препарату швидко втрачають біоцидну активність і зазнають розкладання, що, на нашу думку, мінімізує можливість міграції препарату ланцюгами живлення. Це може слугувати аргументом на користь того, що під час використання препарату для знезараження рідких відходів виробництва або стічних вод, потрапляння ПГМГхл у природні гідроекосистеми його залишкові кількості досить швидко знешкоджуються.

Що стосується вищих наземних рослин, то їх дрібнодисперсне обприскування на дослідних ділянках $0,3 \%$ водним розчином ПГМГхл за дози $0,5-1,0$ л/м² не викликало скільки-небудь помітних негативних змін протягом 7-10 діб спостережень. Крім визначення загальної стійкості неземних рослин до токсиканту, одне із завдань цих експериментів - дослідити КП «поверхня рослини - внутрішні тканини». Як тест-об'єкти використано кропиву дводомну (U. dioica), полин гіркий (A. absinthium), кульбабу звичайну (T. officinale) та тонконіг лучний (P. angustifolia). Визначені хроматографічним методом КП близькі до $0,01 \%$ (табл. 3). На нашу думку, це зумовлено морфологічними особливостями рослин, зокрема, слабопроникними клітинними стінками та специфічною будовою ЦПМ. Через досить велику молекулярну масу та розміри молекул полімеру складно проникнути всередину, у внутрішні тканини стебла або кореня, тому він залишається на поверхні рослини.

Визначення КП у системі «ррунт - рослина (тканини стебла або листки)» показало, що вони також не перевищували $0,01 \%$ (табл. 3). Скільки-небудь помітного впливу складу грунтів або їх рН на КП у системі «грунт - рослина» не виявлено.

Під час проведення профілактичної або вимушеної дезінфекції робочі концентрації ПГМГхл зазвичай становлять $0,05-$ $1,00 \%$. Раніше досліджували також вплив ПГМГхл на зоогідробіонтів. Для них безпечна концентрація препарату становила 0,1 мг/л (або $10^{-5} \%$ ). Рослинна складова водних біоценозів, як виявилося, стійкіша до біоциду; вона витримує на порядок вищі дози ПГМГхл - до 1 мг/л (або $10^{-4} \%$ ). Можна погодитись
3 установленим для води рівнем ГДК - 0,1 мг/л (або 10-5\%). Разом із цим, проведені нами раніше експерименти на культуpax клітин свідчать, що цю концентрацію не можна вважати абсолютно «біологічно нейтральною», вона впливає на проліферацію та клітинний цикл (Mandygra and Lysytsya, 2014). Тому для природних водойм, на нашу думку, ГДК доцільно вражати на порядок нижчою $-10^{-6} \%$.

Таблиця 3

Коефіцієнти переходу ПГМГхл у наземні рослини $(\mathrm{M} \pm \mathrm{m}, \mathrm{n}=5)$

\begin{tabular}{|c|c|c|c|c|}
\hline Вид рослин & $\begin{array}{c}\text { Вихідна } \\
\text { (внесена) } \\
\text { концентрація } \\
\text { ПГМГхл }\left(C_{2}\right), \text { г/л }\end{array}$ & $\begin{array}{c}\text { Кінцева } \\
\text { концентрація } \\
\text { ПГМГхл у } \\
\text { тканинах рослин, } \\
\left(C_{1}\right), \text { мГ/кг } \\
\end{array}$ & $\begin{array}{c}\text { Час, після } \\
\text { внесення } \\
\text { препарату до } \\
\text { відбору } \\
\text { зразків, діб } \\
\end{array}$ & $\begin{array}{c}\text { КП, } \\
\%\end{array}$ \\
\hline \multicolumn{5}{|c|}{ «поверхня рослини - внутрішні тканини» } \\
\hline U. dioica & $3,0 \pm 0,1$ & $0,286 \pm 0,016^{*}$ & 2 & 0,0095 \\
\hline A. absinthium & та сама & $0,203 \pm 0,057$ & 2 & 0,0068 \\
\hline T. officinale & та сама & $0,291 \pm 0,014^{*}$ & 2 & 0,0097 \\
\hline P. angustifolia & та сама & $0,214 \pm 0,042$ & 2 & 0,0070 \\
\hline \multicolumn{5}{|c|}{ «грунт - рослина» } \\
\hline U. dioica & $5,0 \pm 0,2$ & $0,221 \pm 0,045$ & 3 & 0,0044 \\
\hline A. absinthium & та сама & $0,194 \pm 0,053$ & 3 & 0,0038 \\
\hline T. officinale & та сама & $0,406 \pm 0,022^{*}$ & 3 & 0,0081 \\
\hline P. angustifolia & та сама & $0,313 \pm 0,015^{*}$ & 3 & 0,0062 \\
\hline
\end{tabular}

\section{Обговорення}

Під час потрапляння у водойми робочих розчинів препарату вони розводяться в сотні тисяч разів. Крім того, оскільки ПГМГхл володіє помірно вираженими поверхнево активними властивостями, він зв'язує та осаджує (флокуляція) з водного середовища більшість органічних і неорганічних сполук, завислі частинки, іони багатьох металів, поверхнево активні речовини тощо. Завдяки своїм флокулянтним властивостям уже «нейтралізовані» молекули ПАГів осідають на дно, що ускладнює їх міграцію по ланцюгах живлення. Закономірно, що чим більш забрудненою була водойма до потрапляння туди ПГМГхл, тим швидше знижується у воді його концентрація. Тому небезпекних для гідробіонтів концентрацій ПГМГхл на тих водних об'єктах, де проводився екологічний моніторинг, практично не зафіксовано.

Визначення коефіцієнтів переходу для системи «вода рослина» показало, що вони не перевищують $0,1 \%$. А динаміка зміни вмісту ПГМГхл у воді (рис. 2) свідчить, що внаслідок флокуляції ПГМГхл досить швидко осідає на дно акваріума. Далі препарат поступово розщеплюється сапротрофними бактеріями. Крім того, ПГМГхл за певних умов може навіть стимулювати розмноження сапротрофної мікрофлори (табл. 2). Це узгоджується з результатами проведених нами раніше досліджень, де визначалася дія різних солей ПГМГ на інфузорій P. caudatum. Там спостерігали аналогічну закономірність: ПГМГхл і солі ПГМГ з янтарною кислотою у високих концентраціях діяли біоцидно, але їх низькі концентрації $\left(10^{-5}-10^{-4} \%\right)$ проявляли на 2-3-тю добу стимулювальний ефект. Очевидно, зростання чисельності інфузорій пов'язане з тим, що препарат у таких концентраціях спочатку також дещо пригальмовує, а пізніше, навпаки, стимулює ріст сапрофітної мікрофлори основного корму інфузорій.

Внаслідок біорозкладання ПГМГхл може розщеплюватися до окремих проміжних або кінцевих продуктів (рис. 3).

Разом із цим, очевидно, що якщо вміст препарату перевищує $10^{-3} \%$, він негативно впливає на мікро- та макрофлору водних екосистем, у тому числі на мікроскопічні водорості, які, у свою чергу, зазвичай виступають першими елементами трофічного ланцюга. Крім того, планктонні водорості слугують важливим компонентом біологічного очищення стічних вод. Застосовуючи препарат для очищення стічних вод, необхідно враховувати, що його високі кінцеві концентрації можуть знижувати здатність водної екосистеми до біологічного самоочищення. 


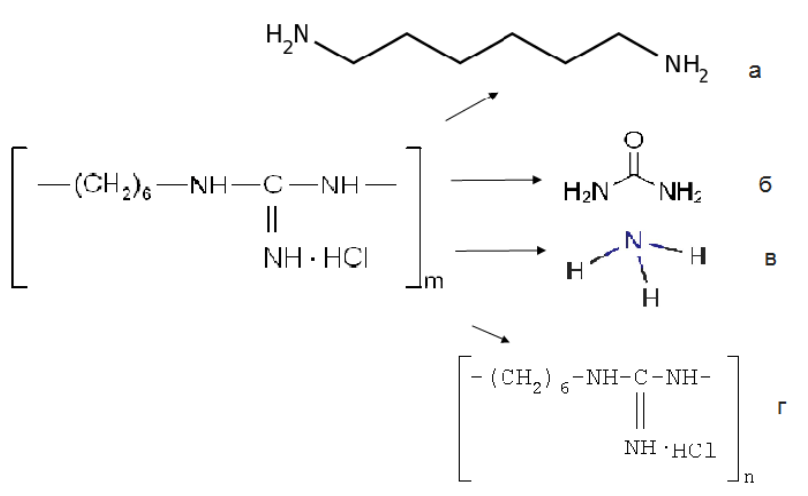

Рис. 3. Основні можливі продукти розкладання полімеру ПГМГхл (m $\geq 7): a$ - гексаметилендіамін, $\sigma$ - карбамід, b- аміак, 2 - низькомолекулярні олігомери $(\mathrm{n} \leq 6)$

Для системи «грунт - рослина» КП не перевищували $0,01 \%$. Актуальність цього дослідження була спричинена як потенцій- ною можливістю забруднення грунтів під час дезінфекції об'єктів ветеринарно-санітарного нагляду, так і наведеними на початку статті прикладами обробки рослин із метою їх захисту та підвищення врожайності. Попередні наші експерименти показали, що препарат може ефективно знешкоджувати у грунті патогенні мікроорганізми та личинки гельмінтів, зокрема стронгілоїдесів (Strongyloides sp.) і диктіокаул (Dictyocalus sp.). Це відкриває перспективи застосування ПГМГхл для знезаражування грунту, забрудненого фекаліями, з метою запобігання зараження тварин у місцях їх скупчень. Наприклад, у Рівненській області це були місця підгодівлі тварин або розміщення солонців у лісових мисливських господарствах.

Такі низькі значення КП у системі «грунт - рослина» пояснюються, на нашу думку, тим, що солі ПГМГхл досить швидко абсорбуються неорганічними та органічними складовими грунту. Це обмежує можливість міграції препарату ланцюгами живлення. Далі ПГМГхл може так само піддаватися як фізикохімічному розкладанню, так i біодеструкції бактеріямисапротрофами або мікроміцетами. Отже, що може відбуватися з препаратом під час потрапляння у біоценози (рис. 4)?

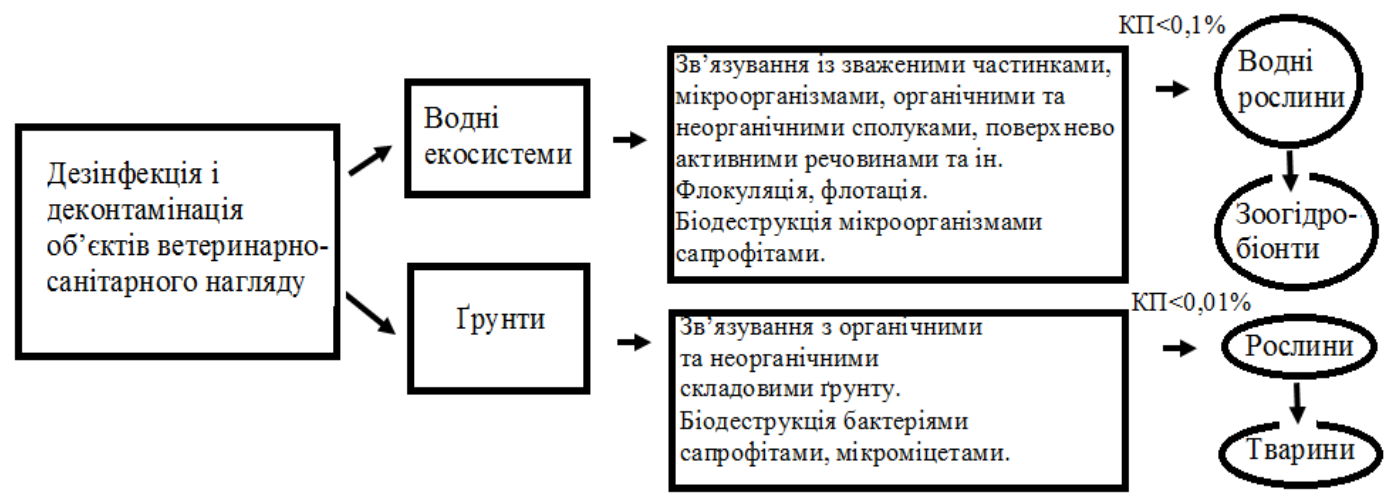

Рис. 4. Поводження препаратів ПГМГхл в екосистемах

Слід зазначити, що під час визначення КП у багатьох рослинних зразках вміст ПГМГхл був на межі чутливості використаних нами методів. Це суттєво впливало на точність вимірювань. У подальшому для відстеження частки цих біоцидів у навколишньому середовищі доцільно використати ефективніші хромато-мас-спектрометричні системи (Buchberger et al., 2013).

У цілому, результати досліджень не дозволяють категорично стверджувати, що ПАГи для макроорганізмів водойм значно менш токсичні, ніж для прокаріотів, як заявляють окремі виробники дезінфектантів. Біоцидні властивості ПГМГхл проявляються фактично за тих самих концентрацій, починаючи від $10^{-3} \%$ і вище. Теоретичний аналіз даних відносно механізмів біоцидної дії ПГМГхл на клітини про- та еукаріотів також не дає переконливих підстав вважати, що ці механізми принципово відмінні. Таким чином, питання біологічної активності ПАГів щодо клітин різних типів вимагає подальшого вивчення. Також доцільно дослідити вплив ПГМГхл на археї, клітинна стінка та ЦПМ яких за будовою та ліпідним складом відрізняються від більшості бактеріальних або еукаріотичних клітин.

\section{Висновки}

Коефіцієнти переходу ПГМГхл у рослини з води не перевищують $0,1 \%$, 3 грунту або поверхні рослини у внутрішні тканини КП - не перевищують $0,01 \%$. Малоймовірно, що у природних умовах ці препарати в тих концентраціях, які зазвичай застосовують під час дезінфекції, будуть становити серйозну загрозу для біоценозів. Під час потрапляння у водойми відбувається багатократне розведення вихідної концентрації препарату, значна частина молекул ПГМГхл «нейтралізується» внаслідок взаємодії з розчиненими у воді неорганічними та органічними речовинами, колоїдами, зваженими частинками, мікроорганізмами тощо. Внаслідок флокуляції біоцид осідає на дно, де розкладається мікроорганізмами мулу, що ускладнює можливість його подальшої міграції по ланцюгах живлення. За достатньо низьких концентрацій солі ПГМГ самі можуть слугувати поживним матеріалом для окремих мікроорганізмів, наприклад для мікроміцетів або деяких бактерій-сапротрофів.

На рівні окремих біоценозів тільки достатньо високі концентрації ПГМГхл (понад $10^{-3} \%$, або 10 мг/л), які діють тривалий час, становлять певну загрозу. Проте через швидке зв'язування із субстратом і локалізацію, дуже обмежену подальшу міграцію ланцюгами живлення та через розкладання їх небезпека для навколишнього середовища, порівняно 3 іншими біоцидами, на нашу думку, менша. Суттєвої відмінності токсичної дії ПГМГхл на про- та еукаріотичні організми не виявлено, тому для природних водойм доцільно вважати порогом безпечності концентрацію ПГМГхл на рівні $10^{-6 \%} \%$, або 0,1 мг/л.

Разом із цим, екологічний моніторинг наслідків застосування ПГМГ-вмісних дезінфектантів на об'єктах господарювання Рівненської області протягом 2011-2015 років не виявив негативних наслідків для природних біоценозів.

\section{References}

Buchberger, T., Himmelsbach, M., \& chberger, W. (2013). Trace analysis of biocidal oligoguanidines in environmental water samples. Journal of Chromatography A, 1318(29), 22-26.

Carmona-Ribeiro, A. M., \& de Melo Carrasco, L. D. (2013). Cationic antimicrobial polymers and their assemblies. International Journal of Molecular Sciences, 14, 9906-9946.

Chakraborty, B., Pal, N., Maiti, P. K., Patra, S. K., \& Ray, R. (2014). Action of newer disinfectants on multidrug resistant bacteria. Journal of Evolution of Medical and Dental Sciences, 3(11), 2797-2813. 
Chang, H.-R., Yang, K.-W., \& Kim, Y.-H. (2006). Environmental risk assessment of polyhexamethyleneguanidine phosphate by soil adsorption/desorption coefficient. Korean Journal of Environmental Agriculture, 25(4), 365-370.

Chindera, K., Mahato, M., Sharma, A. K., Horsley, H., Kloc-Muniak, K., Kamaruzzaman, N. F., Kumar, S., McFarlane, A., Stach, J., Bentin, T., \& Good, L. (2016). The antimicrobial polymer PHMB enters cells and selectively condenses bacterial chromosomes. Scientific Reports, 6, 23121.

Choi, H., Kim, K. J., \& Lee, D. G. (2017). Antifungal activity of the cationic antimicrobial polymer-polyhexamethylene guanidine hydrochloride and its mode of action. Fungal Biology, 121(1), 53-60.

Firdessa, R., Good, L., Amstalden, M. C., Chindera, K., Kamaruzzaman, N. F., Schultheis, M., Röger, B., Hecht, N., Oelschlaeger, T. A., Meinel, L., Lühmann, T., \& Moll, H. (2015). Pathogen- and host-directed antileishmanial effects mediated by polyhexanide (PHMB). PLoS Neglected Tropical Diseases, 9(10), e0004041.

Klimenko, A. (2014). Posivni yakosti ta mikoflora nasinnia kukurudzy za vplyvu preparativ zakhysnoi diji [Sowing seed quality and mycoflora corn under the influence of protective preparations]. Agroecological Journal, 1, 111-113 (in Ukrainian).

Knysh, A. N., Savin, O. R., \& Loschinyn, M. B. (1989). In protocols of V International conference on chemistry and biotechnology (Varna). Biologically Active Natural Products, 2, 370.

Lysytsya, A. V., Mandygra, Y. M., Bojko, O. P., Romanishyna, O. O., \& Mandygra, M. S. (2015). Differential sensitivity of microorganisms to polyhexamethyleneguanidine. Microbiologichny Zhurnal, 77(5), 11-19.

Lysytsya, A., Lyco, S., \& Portuhaj, O. (2013). The polyhexamethyleneguanidine stimulation of seeds growing and cell proliferation. Journal of Materials Science and Engineering B, 3(10), 653-660.

Mac Farlane, R. D., \& Torgerson, D. F. (1976). 252-Cf-Plasma desorption timeof-flight mass spectrometry. International Journal of Mass Spectrometry and Ion Physics, 21, 81-92.

Mandygra, M. S., \& Lysytsya, A. V. (2014). Some aspects of the polyhexamethyleneguanidine salts effect on cell cultures. Agricultural Science and Practice, 1(1), 62-67.

Mashat, B. H. (2016). Polyhexamethylene biguanide hydrochloride: Features and applications. British Joumal of Environmental Sciences, 4(1), 49-55.

Mathurin, Y. K., Koffi-Nevry, R., Guéhi, S. T., Tano, K., \& Oulé, M. K. (2012) Antimicrobial activities of polyhexamethylene guanidine hydrochloride- based disinfectant against fungi isolated from cocoa beans and reference strains of bacteria. Joumal of Food Protection, 75(6), 1167-1171.

Moore, L. E., Ledder, R., Gilbert, P., \& McBain, A. J. (2008). In vitro study of the effect of cationic biocides on bacterial population dynamics and susceptibility. Applied and Environmental Microbiology, 74(15), 4825-4834.

O’Malley, L. P., Collins, A. N., \& White, G. F. (2006). Biodegradability of end-groups of the biocide polyhexamethylene biguanide (PHMB) assessed using model compounds. Journal of Industrial Microbiology and Biotechnology, 33(8), 677-684.

Opryshko, N. O. (2013). Doslidzhennja vlastyvostej preparatu ekoton dlja ekologobezpechnyh tehnologij vyroshhuvannja ogirka [Investigation of properties of preparation ecoton for environmentally safe technologies of cucumber production]. Agrobiology, 11, 104-107 (in Ukrainian).

Oule, M. K., Quinn, K., Dickman, M., Bernier, A. M., Rondeau, S., Moissac, D., Boisvert, A., \& Diop, L. (2012). Akwaton, polyhexamethyleneguanidine hydrochloride-based sporicidal disinfectant: A novel tool to fight bacterial spores and nosocomial infections. Journal of Medical Microbiology, 61, 1421-1427.

Prasanthi, K., Murty, D. S., \& Saxena, N. K. (2012). Evaluation of antimicrobial activity of surface disinfectants by quantitative suspension method. International Journal of Research in Biological Sciences, 2(3), 124-127.

Sysoev, A. A., \& Artaev, V. B. (1991). Mass-spektrometrija s ionizaciej oskolkami delenija jader kalifornija-252 [Mass spectrometry with ionization of fission fragments of californium-252]. Journal of Analytical Chemistry, 46(1), 6-18 (in Russian).

Timofeeva, L., \& Kleshcheva, N. (2011). Antimicrobial polymers: Mechanism of action, factors of activity, and applications. Applied Microbiology and Biotechnology, 89(3), 475-492.

Vointseva, I. I., \& Gembitsky, P. A. (2009). Polyguanidiny - disinfectiony sredstva i polifunctionalnye dobavki $\mathrm{v}$ kompozicionye materialy [Polyguanidines - disinfecting agents and multifunctional additives to composite materials]. LKM-press, Moscow (in Russian).

Zhou, Z., Zheng, A., \& Zhong, J. (2011). Interactions of biocidal guanidine hydrochloride polymer analogs with model membranes: A comparative biophysical study. Acta Biochimica et Biophysica Sinica (Shanghai), 43(9), 729-737. 